\title{
Післятравматичний коксартроз і особливості його перебігу
}

\author{
Г. В. Гайко, О. В. Калашніков, А. Т. Бруско
}

Інститут травматології та ортопедії НАМН України, м. Київ, Україна

\begin{abstract}
Резюме. На основе данных литературы и собственного клинико-рентгенологического обследования определены особенности течения патологического процесса и разработана патогенетическая схема его развития. Определено, что течение заболевания отвечает тяжести полученной травмы. Внедрение разработанной патогенетической схемы развития остеоартроза тазобедренного сустава будет способствовать лучшему пониманию звеньев патогенеза этого сложного ортопедического заболевания, улучшит результаты его лечения и профилактики этой патологии.
\end{abstract}

Ключевые слова: коксартроз, травма, формы течения, схема развития.

\begin{abstract}
Summary. On the basis of the literature data and own clinical and $x$-ray survey of 32 patients with traumatic can stage 4 on J. H. Kellgren and J. S. Lavrence, which were treated in the clinic, defines the characteristics of the course and is designed pathogenetic scheme of the development of the pathological process. Introduction of the developed pathogenetic of the scheme of development of osteoarthritis of the hip joint will contribute to a better understanding of the links of the pathogenesis of this complex orthopedic diseases, improve the results of treatment and prevention of this disease.
\end{abstract}

Key words: coxarthrosis, trauma, forms currents, circuit development.

Постановка проблеми. Деформуючий артроз кульшового суглоба - коксартроз (КА) найпоширеніше дегенеративно-дистрофічне захворювання опорно-рухової системи. В різних регіонах світу його частота коливається в межах $7-25 \%$ дорослого населення. КА в $60 \%$ випадків призводить до зниження працездатності та в $11,5 \%$ - до інвалідності [3, 9].

Усе це свідчить про високу медичну та соціальну значущість КА як проблеми, що призводить до значних економічних втрат. Тому обгрунтування нових підходів до ранньої діагностики, профрілактики та лікування хворих на КА залишається на сьогодні актуальним питанням сучасної ортопедії.

Класифрікація КА, згідно з міжнародною статистичною класифрікацією хвороб та проблем, пов'язаних зі здоров'ям, виділяє первинний (ідіопатичний) та вторинний, за поширеністю - однобічний і двобічний, за етіологією - диспластичний та післятравматичний (ПТ КА) [7].

Клінічна картина КА травматичної етіології залежить від характеру травми й ефективності iї лікування [5, 6]. До основних фракторів, що призводять до розвитку цієї патології, відносять порушення кровопостачання головки стегнової кістки та дисконгруентність суглобових поверхонь при залишковій їх дефрормації. Можливе також поєднання обох цих фракторів. До причин розвитку ПТ КА, згідно з класифікацією
Американської асоціації ревматологів (ACR), можна віднести також хронічну травматизацію, пов'язану з професійною діяльністю [12].

Якщо питання етіології та патогенезу остеоартрозу знайшли своє висвітлення у літературних джерелах вітчизняних та зарубіжних авторів, то проблема перебігу цієї тяжкої патології фактично не розглядалася. Вважають, що КА характеризується довгим хронічним перебігом із прогресуючим розвитком клінічної картини. За повільного розвитку захворювання довго зберігається працездатність хворих [15]. Поряд 3 цим деякі автори виділяють КА зі швидким перебігом та кістково-суглобовою деструкцією [10, 11]. Так, деякі учені виділяють малосимптомну, маніфестну повільнопрогресуючу та маніфестну швидкопрогресуючу форми КА [8].

Зважаючи на невелику кількість публікацій про перебіг остеоартрозу кульшового суглоба, на сьогодні відсутнє загальновизнане уявлення про нього, що безумовно впливає на вибір методів профрілактики та подальшого лікування.

Мета дослідження - визначити особливості перебігу остеоартрозу кульшового суглоба травматичної етіології та розробити патогенетичну схему розвитку патологічного процесу.

Матеріали і методи дослідження. У ході роботи було опрацьовано дані літературних джерел та клініко-рентгенологічне обстеження 32 хворих із KA IV стадії за J. Н. Kellgren та 
ТАБЛИЦЯ 1 - Класифікація перебігу післятравматичного остеоартрозу кульшового суглоба

\begin{tabular}{|c|l|l|}
\hline № $\mathbf{n} / \mathbf{n}$ & \multicolumn{1}{|c|}{$\begin{array}{c}\text { Форма } \\
\text { перебігу }\end{array}$} & \multicolumn{1}{|c|}{$\begin{array}{c}\text { Критерії прогресування, } \\
\text { років }\end{array}$} \\
\hline 1 & Швидка & $\begin{array}{l}\text { П'ять чи менше з моменту травми до } \\
\text { кінцевої стадії КА }\end{array}$ \\
\hline 2 & Помірна & Від п'яти до десяти років \\
\hline 3 & Повільна & Понад десяти років \\
\hline
\end{tabular}

J. S. Lavrence [14], які проходили лікування в клініці.

Пацієнтам при клінічному обстеженні визначали професійний анамнез хвороби, функціональний стан кульшових суглобів за класифікаці$€ ю$ W. H. Harris [13]. Рентгенологічне обстеження виконували у двох проекціях із визначенням стадії патологічного процесу [14]. Визначення особливостей перебігу остеоартрозу кульшового суглоба травматичної етіології проводили згідно 3 розробленою нами робочою класифрікацією перебігу остеоартрозу кульшового суглоба [4], представленою в таблиці 1.

Було проведено статистичну обробку отриманого матеріалу.

Основою розробки патогенетичної схеми розвитку ПТ КА були експериментальні дослідження, проведені на здорових кролях, яких піддавали тривалому статичному навантаженню колінного суглоба [1, 2]. Доведено, що нормальне дифузійне живлення суглобового хряща реалізується тільки в умовах динамічних навантажень, тоді як статичні навантаження спричиняють у суглобовому хрящі розвиток дистрофрічного та некротичного процесів. Наведені результати експериментальних досліджень переконливо свідчать, що тривалі статичні навантаження викликають некроз суглобового хряща. Крім цього, показано, що скомпроментований суглобовий хрящ під впливом динамічних навантажень піддається руйнуванню та розсмоктуванню. Це підтверджено даними світової літератури. Багато учених $\epsilon$ прибічниками механофрункціональної теорії патогенезу КА [5].

Результати дослідження та їх обговорення. Розподіл різних етіологічних чинників та форми прогресування ПТ КА представлено в таблиці 2.

Найчастіше зустрічалася повільна фрорма прогресування - 71,8 \% загальної кількості. Вона $\epsilon$ характерною ознакою ПТ КА у спортсменів (88 \%) та пов'язана з мікротравматизацією хряща. У хворих із наслідками травм повільна форма прогресування спостерігалася у випадках біомеханічної невідповідності внаслідок варусної чи вальгусної деформації ураженої кінцівки.
У хворих із швидкою формою прогресування в анамнезі спостерігали високоенергетичну травму з ушкодженням кісткових структур.

Функціональна активність кульшового суглоба залежала від форми прогресування ПТ КА. Найнижчі показники відмічено при швидкій фрормі прогресування патологічного процесу (табл. 3).

Таким чином, при КА перебіг захворювання відповідав передовсім тяжкості отриманої травми.

ШВидку форму прогресування КА спостерігали у хворих після тяжких уражень кульшового суглоба (центральний вивих стегна, переломи вертлюгової западини). У спортсменів, у яких розвиток КА відбувався внаслідок функціонального перевантаження (мікротравматизація суглобового хряща), спостерігали повільну форму перебігу захворювання, що пояснюється молодим віком хворих та високими адаптаційно-компенсаторними можливостями опорно-рухової системи.

При розробці патогенетичної схеми розвитку ПТ КА ми користувалися механофункціональною теорією патогенезу. Згідно з цією теорією, розвиток дегенеративно-дистрофрічного процесу в суглобовому хрящі, субхондральної кістки та капсули суглоба викликається ффункціональним перенавантаженням хряща, що обумовлено або його біологічною неповноцінністю, або великим навантаженням. Цей механізм розвитку первинного KА $є$ базисом, на якому залежно від етіологічних чинників розроблено патогенетичну схему розвитку патологічного процесу. Фонові чинники - мікротравматизація хряща (у професійних спортсменів), невірно зрощені переломи заднього краю вертлюгової западини, варусні та вальгусні деформації кінцівок тощо - викликають

ТАБЛИЦЯ 2 - Етіологічні чинники та форми прогресування коксартрозу

\begin{tabular}{|l|c|c|c|c|}
\hline \multicolumn{1}{|c|}{$\begin{array}{c}\text { Етіологічний } \\
\text { чинник }\end{array}$} & \multicolumn{3}{|c|}{ Форма перебігу, n, \% } & \multirow{2}{*}{ Усього } \\
\cline { 2 - 4 } & Швидка & Помірна & Повільна & \\
\hline Наслідки травм & $3(20,0)$ & $4(26,7)$ & $8(53,3)$ & $15(46,9)$ \\
\hline $\begin{array}{l}\text { Професійна } \\
\text { шкідливість, } \\
\text { пов' язана з мікро- } \\
\text { травматизацією }\end{array}$ & - & $2(11,8)$ & $15(88,2)$ & $17(53,1)$ \\
\hline Усього & $3(9,4)$ & $6(18,8)$ & $23(71,8)$ & $32(100)$ \\
\hline
\end{tabular}

ТАБЛИЦЯ 3 - Залежність бальної клінічної оцінки кульшового суглоба за Harris від форми прогресування післятравматичного коксартрозу

\begin{tabular}{|l|c|c|}
\hline \multirow{2}{*}{$\begin{array}{c}\text { Форма } \\
\text { прогресування }\end{array}$} & \multicolumn{2}{|c|}{ Кількість балів } \\
\cline { 2 - 3 } & Однобічне ураження & Двобічне ураження \\
\hline Швидка & $24 \pm 0,7$ & \\
\hline Помірна & $30 \pm 0,4$ & $28 / 82 \pm 0$ \\
\hline Повільна & $36 \pm 0,6$ & $32 / 64 \pm 0,7$ \\
\hline
\end{tabular}


розвиток анатомо-функціональної невідповідності, що призводить до перевантаження, і зумовлюють механізм розвитку КА, аналогічний до первинного.

На перебіг ПТ КА, на нашу думку, впливає розвиток анатомо-фрункціональної невідповідності внаслідок інконгруентності суглобової поверхні, травми (переломи та вивихи кульшової западини, мікротравматизація хряща у спортсменів) (рис. 1). На розвиток патологічного процесу впливають також збільшення маси тіла, статевовікові особливості пацієнта, а також загальні порушення метаболізму (D-гіповітаміноз тощо).

\section{Висновки:}

1. Перебіг остеоартрозу кульшового суглоба післятравматичного генезу відповідає тяжкості отриманої травми.

2. Швидку форму прогресування післятравматичного коксартрозу спостерігали у хворих після тяжких уражень кульшового суглоба (центральний вивих стегна, переломи вертлюгової западини). У спортсменів, у яких розвиток КА відбувався внаслідок фрункціонального перевантаження (мікротравматизація суглобового хряща), спостерігали повільну фрорму перебігу.

\section{Література}

1. Бруско А. Т. Экспериментальное обоснование роли статико-динамических нагрузок в возникновении и развитии десормирующего артроза / А. Т. Бруско, Ю. И. Браду // Ортопед., травматол. и протез. - 1995. - № 3. - С. $47-50$.

2. Гайко Г. В. Сучасні підходи до профрілактики та лікування остеоартрозу / Г. В. Гайко, А. Т. Бруско // Літопис травматології та ортопедії. - 2008. - № 1-2. - С. 157-160.

3. Гайко Г. В. Остеоартроз - новий підхід до його профрілактики / Г. В. Гайко, А. Т. Бруско, Є. В. Лимар // Вісн. ортопед., травматол. та протезув. - 2005. - № 2. C. 5-11.

4. Гайко Г. В. Визначення факторів ризику швидкого прогресування остеоартрозу кульшового суглоба / Г. В. Гайко, О. В. Калашніков // Медицина сьогодні і завтра. - 2012. - Т. 54, №1. - С. 48-52.

5. ГурьеВ В. Н. Коксартроз и его оперативное лечение / В. Н. Гурьев. - Таллин: Вальгус, 1984. - 341 с.

6. Зоря В. И. Посттравматический протрузионный коксартроз / В. И. Зоря, Е. В. Проклова // Вестник травматологии и ортопедии. - 2001. - № 4. - С. 38-41.

7. Корж Н. А. Остеоартроз: консервативная терапия / Н. А. Корж, Н. В. Дедух, И. А. Зупанец. - Х.: Золотые страницы, 2007. - 424 с.

8. ОкорокоВ А. Н. Лечение болезней внутренних органов / А. Н. Окороков. - М.: Мед. лит., 2000. - Т. 2. $608 \mathrm{c.}$

9. Тихилов Р. М. Десормирующий артроз тазобедренного сустава (клиника, диагностика, хирургическое лечение) / Р. М. Тихилов., В. М. Шаповалов. - СПб. Правда, 1999. - 112 с.

10. Batra S. Rapidly destructive osteoarthritis of the hip joint: a case series / S. Batra, M. Batra, A. McMurtrie // J. Orthop. Surg. Res. - 2008. - № 3. - P. 1749-1799.

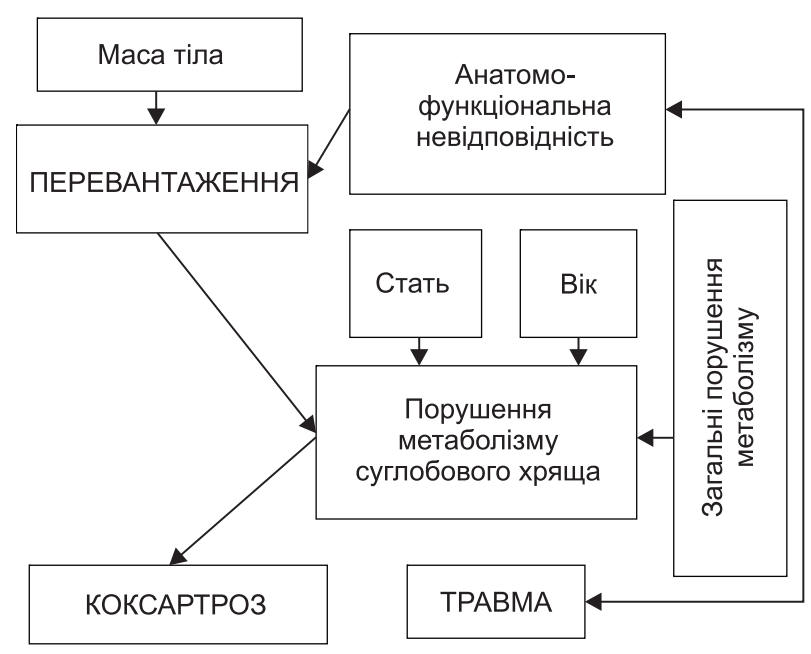

Рисунок 1 - Патогенетична схема розвитку післятравматичного коксартрозу

3. Впровадження розробленої патогенетичної схеми розвитку остеоартрозу кульшового суглоба сприятиме кращому розумінню ланок патогенезу цього складного ортопедичного захворювання, покращить результати його лікування та профрілактики.

\section{References}

1. Brusko A. T. Experimental substantiation of the role of static and dynamic loads in the origin and development of deforming arthrosis / A. T. Brusko, Yu. I. Bradu // Orthopaedics, Traumatology and Prosthetics. - 1995. № 3. - P. 47-50.

2. Gaiko G. V. Current approaches to prevention and treatment of osteoarthritis / G. V. Gaiko, A. T. Brusko // Litopys travmatologii ta ortopedii. - 2008. - № 1-2. P. $157-160$.

3. Gaiko G. V. Osteoarthritis - a new approach to its prevention / G. V. Gaiko, A. T. Brusko, E. V. Lymar / / Visnyk ortopedii, travmatologii i protezuvannia. - 2005. - № 2. P. 5-11.

4. Gaiko G. V. Determination of risk factors for rapid progression of osteoarthritis of the hip joint / G. V. Gaiko, O. V. Kalashnikov // Medytsyna siogodni i zavtra. 2012. - V. 54, № 1. - P. 48-52.

5. Guriev V. N. Coxarthrosis and its surgical treatment / V. N. Guriev. - Tallinn: Valgus, 1984. $-341 \mathrm{p}$.

6. Zoria V. I. Post-traumatic protrusion coxarthrosis / V. I. Zoria, E. V. Proklova // Vestnik travmatologii I ortopedii. - 2001. - № 4. - P. 38-41.

7. Korzh N. A. Osteoporosis: conservative therapy / [N. A. Korzh, A. N. Khvisiuk, N. V. Dedukh et al. ] - Kharkov: Zolotye Stranicy, 2007. - $424 \mathrm{p}$.

8. Okorokov $A$. N. Treatment of diseases of the internal organs / A. N. Okorokov. - Moscow: Medicinskaia literatura, 2000. - V. 2. -608 p.

9. Tikhilov R. M. Deforming arthrosis of the hip joint (clinic, diagnostic, surgical treatment) / R. M. Tikhilov, V. M. Shapovalov. - St. Petersburg: Pravda, 1999. - 112 p.

10. Batra S. Rapidly destructive osteoarthritis of the hip joint: a case series / S. Batra, M. Batra, A. McMurtrie // J. Orthop. Surg. Res. - 2008. - № 3. - P. 1749-1799. 
11. Bock G. W. Rapidly destructive hip disease: clinical and imaging abnormalities / G. W. Bock, A. Garcia, M. H. Weisman // Radiology. - 1993. - № 186. - P. 461-466.

12. Development of criteria for the classification and reporting of osteoarthritis: classification of osteoarthritis of the knee / [R. Altman, D. Bloch, G. Bole et al.] // Arthritis Rheum. - 1986. - № 29. - P. 1039-1049.

13. Harris $W$. H. Traumatic arthritis of the hip after dislocation and acetabular fractures treatment by mold arthroplasty. An end result study using a new method of result evaluation / W. H. Harris // J. Bone Joint Surg. Am. 1969. - Vol. 51-A. - P. 737-743.

14. Kellgren J. Radiological assessment of osteoarthritis / J. Kellgren, J. Lawrence // Ann. Rheum. Dis. - 1957. Vol. 16. - P. 494-501.

15. Spector T. D. How serious is knee osteoarthritis? / T. D. Spector, D. J. Hart // Ann Rheum Dis. - 1992. № 51. - P. 1105-1106.
11. Bock G. W. Rapidly destructive hip disease: clinical and imaging abnormalities / G. W. Bock, A. Garcia, M. H. Weisman // Radiology. - 1993. - № 186. - P. 461-466.

12. Development of criteria for the classification and reporting of osteoarthritis: classification of osteoarthritis of the knee / [R. Altman, D. Bloch, G. Bole et al. ] // Arthritis Rheum. - 1986. - № 29. - P. 1039-1049.

13. Harris W. H. Traumatic arthritis of the hip after dislocation and acetabular fractures treatment by mold arthroplasty. An end result study using a new method of result evaluation / W. H. Harris // J. Bone Joint Surg. Am. 1969. - Vol. 51-A. - P. 737-743.

14. Kellgren J. Radiological assessment of osteoarthritis / J. Kellgren, J. Lawrence // Ann. Rheum. Dis. - 1957. Vol. 16. - P. 494-501.

15. Spector T. D. How serious is knee osteoarthritis? / T. D. Spector, D. J. Hart // Ann. Rheum. Dis. - 1992. № 51. - P. 1105-1106. 